This PDF is a selection from an out-of-print volume from the National Bureau of Economic Research

Volume Title: Economics of the Family: Marriage, Children, and Human Capital

Volume Author/Editor: Theodore W. Schultz, ed.

Volume Publisher: University of Chicago Press

Volume ISBN: 0-226-74085-4

Volume URL: http://www.nber.org/books/schu74-1

Publication Date: 1974

Chapter Title: Benefits of Women's Education within Marriage

Chapter Author: Lee Benham

Chapter URL: http://www.nber.org/chapters/c2972

Chapter pages in book: (p. 375 - 394) 


\section{Benefits of Women's Education within Marriage}

\section{Lee Benham}

University of Chicago

Studies of the returns to education have generally investigated the relationship between individuals' investments in formal education and on-the-job training and their labor-market productivity. It is well recognized, however, that other factors besides formal education and training contribute to a person's effective stock of human capital (and hence to productivity); these factors include early childhood environment, parents' behavior (see Dugan 1969), and associations with other individuals. There is general agreement, for example, that a child's development is affected by the ability and performance of peers in school. At a later stage, a significant part of an individual's college and graduate education appears to result from association with fellow students, the more able students contributing to the education of all. After formal schooling is completed, close associates are likely to continue to affect an individual's further educational development and to influence the rate of depreciation of the individual's stock of knowledge.

One of the more persuasive explanations of the observed strong positive relationship between formal education and labor-market productivity is that, in addition to providing specific skills, formal education improves the individual's ability to acquire and assimilate information, to perceive and understand changing conditions, and to respond effectively. ${ }^{1}$ From

I thank Alexandra Benham for comments and substantial assistance throughout this study; Gary Becker, Solomon Polachek, Robert Michael, and T. W. Schultz for helpful comments; and Elayne Howard for analyzing the data. The investigation was partly supported by $\mathbf{i}$ HS grant HS00080 from the National Center for Health Services Research and Development.

${ }^{1}$ In his study of migration, Aba Schwartz (1968) found results consistent with the hypothesis that one effect of education is to reduce the cost of obtaining information. The responsiveness of individuals to lifetime-earnings differentials was found to increase monotonically with education. Finis Welch (1970) distinguishes between the worker effect and the allocative effect of education. He argues: "Much of the 'leverage' associated with added schooling is drawn from the dynamic implications of changing technology." That is, education enables an individual to adapt more rapidly to changing conditions. 
this perspective, associates can contribute to a person's effective stock of education in at least three ways: (1) by providing a close substitute for the person's own formal education by extending information and advice, (2) by helping the person acquire specific skills, and (3) by helping the person acquire general skills related to information acquisition and assimilation and coping with change.

There are obvious limitations to the extent to which one person can benefit from another's experience and advice. Some individuals are better able than others to reap such benefits. Nevertheless, persons having exposure to individuals with a greater or different stock of knowledge should on average benefit from such exposure. ${ }^{2}$ To the extent that this true, an individual's effective stock of acquired abilities will be a function not only of his own formal education and job experience but also of associates' education, the incentives the associates have to share their knowledge, and the length of the association. This paper investigates this transmission of educational benefits in one type of association: marriage.

Marriage is distinguished from most other nonmarket associations in that there are greater incentives to share acquired abilities within the household: both current and future benefits of increased knowledge by either family member are typically shared. The costs of sharing would also appear to be lower because the transactions cost of communication within the household, given the proximity of spouses, is likely to be less than in other types of associations. For these reasons, the household would appear to provide a good opportunity to examine the benefits of association.

In the traditional human capital literature, the individual is viewed as a firm whose earnings $\left(E_{t}\right)$ at time $t$ are a function of the individual's stock of human capital $\left(H_{t}\right)$, which in turn is composed of two elements, the individual's net investment in formal education $\left(S_{t}\right)$ and net investment in postschool on-the-job training $\left(P_{t}\right): E_{t}=E\left(S_{t}, P_{t}\right)$.

In the present study, the household firm composed of husband and wife is investigated rather than the individual. The assumption is made that the effective stock of human capital for each marriage partner $\left(H_{t}^{h *}\right.$ or $\left.H_{t}^{w *}\right)$ is a positive function of the individual stock of human capital of each spouse within the household:

$$
\begin{aligned}
& H_{t}^{w *}=H\left(H_{t}^{w}, H_{t}^{h}\right) \text { and } \\
& H_{t}^{H *}=H\left(H_{t}^{w}, H_{t}^{h}\right),
\end{aligned}
$$

where $\partial H_{t}^{i *} / \partial H_{t}^{j}>0$ for $i, j=h, w$. Both the market and the nonmarket

\footnotetext{
2 The market provides this type of advisory service. Lawyers and professional counselors are among those whose stock in trade is advice. Actors, politicians, and athletes frequently hire managers to guide their careers.
} 
productivity of individuals within the household are functions of $H_{t}^{*}{ }^{3}$ Therefore, increments to the capital stock of either spouse should be reflected in the productivity of both. While this model could thus be used to examine both market and nonmarket productivity of husband and wi fe, the following analysis is limited to an examination of the relationship be tween husband's market productivity and both spouses' capital stock. ${ }^{4}$ The initial relationship examined is the extent to which the earnings of a married man are positively related to his wife's stock of human capital, measured here by the wife's years of schooling. To investigate this, education of wives is incorporated into the model developed by Mincer (1970a) to estimate the returns to men's education. ${ }^{5}$ The logarithm of husband's earnings is given as a function of the years of formal education of each spouse and the years of employment experience of the husband.

The specification of the model is as follows:

$$
\ln \mathrm{EARN}=\alpha+\beta_{1} \mathrm{EDH}+\beta_{2} \mathrm{EDW}+\beta_{3} \mathrm{EXP}+\beta_{4} \mathrm{EXP}^{2}+\mu,
$$

where $\ln \mathrm{EARN}=\log _{e}$ annual earnings of husband in family with husband and wife present, $\mathrm{EDH}=$ years of schooling completed by husband, EDW = years of schooling completed by wife, and EXP = years of work experience of husband. ${ }^{6}$ The coefficients $\beta_{1}$ and $\beta_{2}$ are estimates of the percentage earnings differentials to husband's and wife's formal education, respectively, in terms of husband's market earnings, given the other spouse's years of formal education and the husband's work experience. ${ }^{7}$ Husband's work experience is entered in quadratic form to approximate the postschool investment pattern usually assumed.

\section{Data}

To estimate this model, data from three samples of the population of the United States were used: the 1/1,000 sample of the U.S. Census for 1960 (U.S. Bureau of the Census 1964), a 1963 health survey conducted by the

\footnotetext{
${ }^{3}$ For a survey of current work on nonmarket productivity within the family, see T. W. Schultz (1972a).

${ }^{4}$ Sorting out the impact of household capital on the wife's market productivity appears to be considerably more difficult than doing so for the husband's. Women have a lower labor-force participation rate than men, and their participation is negatively related to husbands' earnings (which are in turn positively related to husbands' education). A lower participation rate means less job experience and lower market earnings. It is beyond the scope of this paper to separate the effect of husband's human capital on wife's job experience from the effect of husband's human capital on her market productivity.

${ }^{5}$ This model is restrictive in that, for each spouse, the same percentage earnings differentials are assumed for all years of schooling.

6 The number of years of job experience is here estimated as age minus years of schooling minus 6 .

${ }^{7}$ Under a set of assumptions discussed in Mincer (1970a), $\beta_{1}$ is an estimate of the rate of return to men's formal education.
} 
Center for Health Administration Studies of the University of Chicago and the National Opinion Research Center (Andersen and Anderson 1967), and the 1967 Survey of Economic Opportunity (SEO) conducted by the Bureau of the Census for the Office of Economic Opportunity. The subsamples used in this study include only married white males with spouse present, not living on farms, and having positive earnings in the survey year. ${ }^{8}$

\section{Results}

Table 1A shows the estimates of this model obtained from the three data sets. The coefficient of wife's education is positive and significantly greater than zero in all cases. The simple null hypothesis that education of wife is unrelated to husband's earnings can be rejected. Considering that three separate data sources are used, the absolute value of $\beta_{2}$ and the ratio $\beta_{2} / \beta_{1}$ are remarkably stable. Given the level of husband's education and his years of work experience, his earnings increase between 3.0 and 4.1 percent for each year of his wife's education. ${ }^{9}$

To examine the effects of wife's education on her husband's wages and on his work time separately, the basic equation was reestimated using the Census data with In weekly wage rather than In annual earnings as the dependent variable. ${ }^{10}$ An additional estimate of this type was made excluding husbands who were not working full time. The results, shown in table 2, suggest that from 20 to 25 percent of the increase in a husband's earnings is due to increases in weeks worked, and the remainder is due to higher wages.

While these results are open to alternative interpretation, the observed associations are hardly negligible, and they would appear to merit further inquiry. If it can be established that all or even a substantial part of these returns through a husband's earnings are due to the benefits of his wife's

\footnotetext{
${ }^{8}$ The characteristics of the subsamples differed in some minor details. See notes to table 1 for subsample descriptions.

${ }^{9}$ For purposes of comparison, $\beta_{1}$ is also calculated in table IB with wife's education excluded from the estimating equation. In these estimates, the percentage differentials in husbands' earnings associated with their own education range from 8.1 to 9.0 percent. These estimates are lower than others have made. Part of the reason is that earnings differentials associated with the education of never-married men and divorced men are higher, although their absolute earnings are lower.

10 It is not obvious a priori whether a wife's education is positively or negatively associated with a husband's market-work time. An increase in a wife's education leads to increases in her own market and nonmarket productivity. Specialization within the family between market and nonmarket activity will depend in part on the comparative advantage of each spouse in these activities. If education increases the wife's market production relative to her nonmarket productivity, this will increase the incentive for her to specialize more in market activities and raise the incentive for her husband to spend more time in nonmarket production. However, insofar as a wife's education increases her husband's market productivity, an opposite effect occurs.
} 


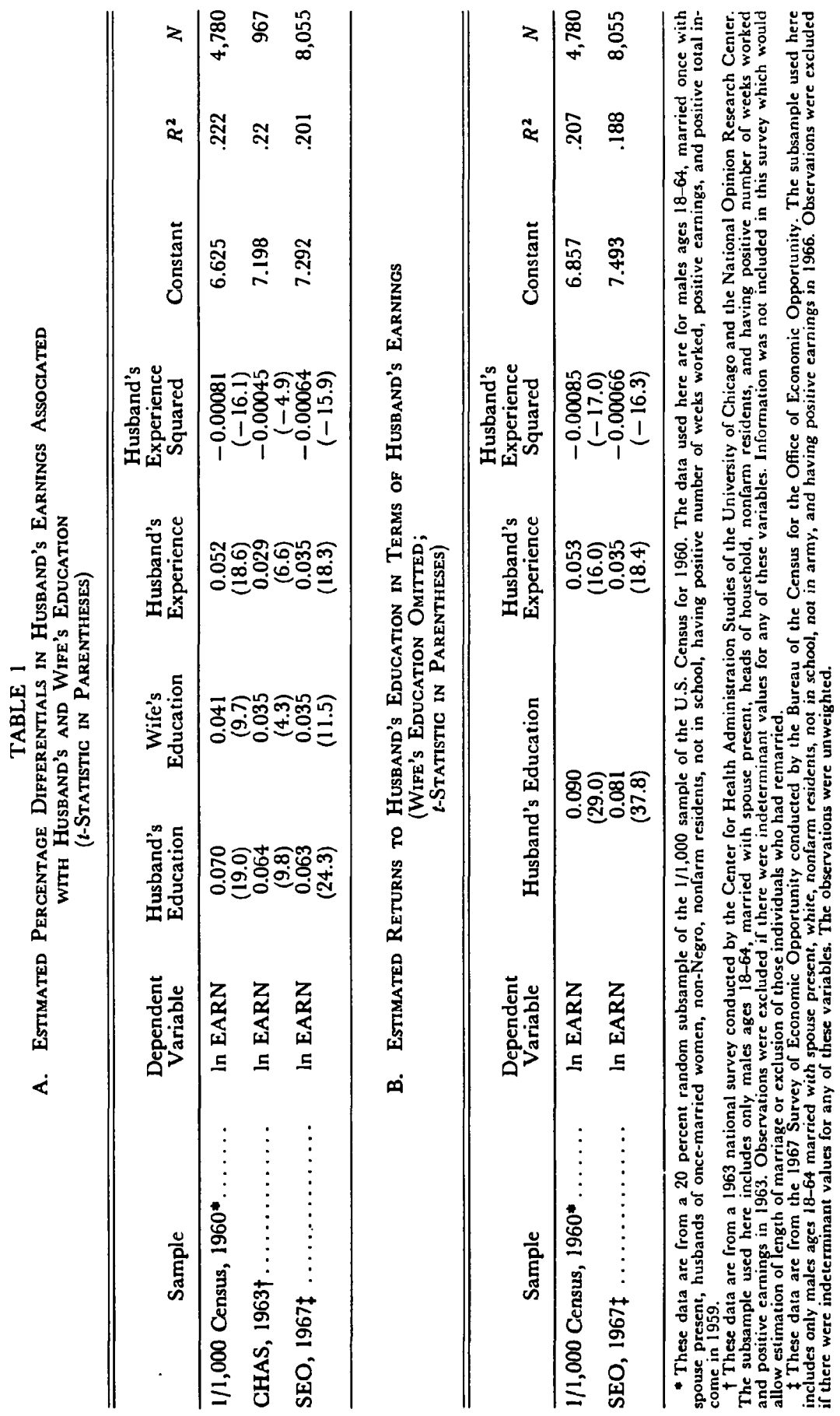




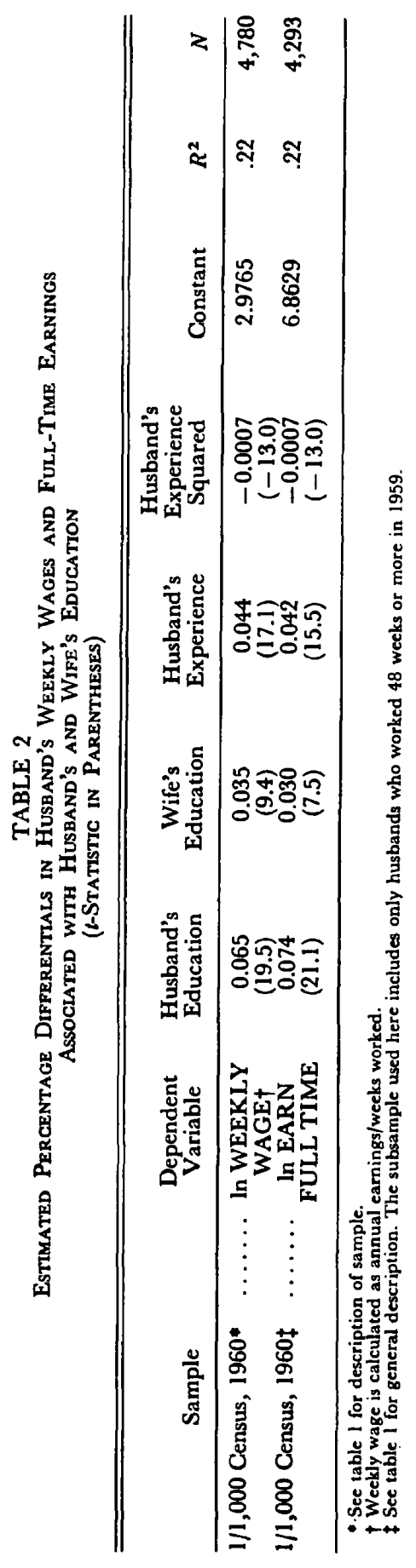


education, this has important implications both for our interpretation of the returns to education for men and women and for our understanding of the market returns to marriage.

The assumption underlying the previous specification is that a wife's education has a constant percentage impact on earnings over the life cycle. If the view is taken that the husband's earnings reflect an accumulation of the stock of acquired abilities (human capital) within the household, there are several reasons for expecting earnings to be a function not only of the wife's education but also of the length of marriage. First, the incentives for the husband to acquire on-the-job training are a positive function of the expected time in labor-market activities. Since his labormarket time is positively related to his wife's education, as shown in table 2, his incentive to invest in on-the-job training should also be associated with his wife's education. ${ }^{11}$ Second, if the complementarity between formal education and postschool investment also holds between a wife's formal education and her husband's postschool investment, this would also tend to raise the husband's postschool investment as a function of his wife's education. Third, if a wife's education increases her husband's earnings by reducing the depreciation rate of his stock of knowledge, then the full impact of the wife's education would not be observed immediately upon marriage but only over time as different rates of depreciation resulted in different earnings patterns. Further, if costs of communicating knowledge or learning are inversely related to the time span available, then a husband is not likely to gain the full benefit of his wife's education at the start of marriage. ${ }^{12}$

Although the quantitative importance of each of these arguments in postmarriage capital accumulation is not known, they all imply that the husband's absolute earnings should increase, at least initially, as a function of the length of marriage. While the a priori case is less clear for the percentage differentials in earnings, these arguments suggest increasing percentage differentials during the first years of marriage. To examine the life-cycle pattern of husband's earnings as a function of wife's education,

\footnotetext{
11 Since the labor-force participation of wives and the interval between marriage and first births are positively correlated with wives' education, women could also be financing more on-the-job training for their husbands.

${ }^{12}$ Even the benefits provided by the wife's direct advice and knowledge (rather than by her increasing her husband's stock of knowledge and skills) are not necessarily realized at the time the information is available to her husband. The economic consequences of many career decisions are observable only after several years. This point could also be made concerning the benefits of one's own education. Even with no postschool investment, the better-educated person will presumably be better able to anticipate events. Since the benefits derived from this improved ability to predict are observed only after some period of time (i.e., after the person has been able to profit as a result of his earlier decisions), the relative (observed) earnings over time should reflect these differential abilities in anticipating change, and those who anticipate better may have increasing relative earnings over time.
} 
TABLE 3

Estimated Percentage Difperentials in Husband's Earnings Associated WTTH WIFE's Education BY Length of MarRiage ( $t$-Statistic in Parentheses)

\begin{tabular}{|c|c|c|c|c|}
\hline Sample & $\begin{array}{l}0-10 \text { Years } \\
\text { of Marriage }\end{array}$ & $\begin{array}{l}\text { 10-20 Years } \\
\text { of Marriage }\end{array}$ & $\begin{array}{c}20-30 \text { Years } \\
\text { of Marriage }\end{array}$ & $\begin{array}{l}30-40 \text { Years } \\
\text { of Marriage }\end{array}$ \\
\hline $\begin{array}{l}1 / 1,000 \text { Census, } 1960 * \\
\text { SEO, 1967* } \ldots \ldots \ldots\end{array}$ & $\begin{array}{l}0.032 \\
(4.1) \\
N=1,549 \\
=0.031 \\
(6.0) \\
N=2,610\end{array}$ & $\begin{array}{c}0.041 \\
(6.5) \\
N=1,614 \\
0.044 \\
(8.3) \\
N=2,432\end{array}$ & $\begin{array}{c}0.060 \\
(5.9) \\
N=980 \\
0.036 \\
(5.6) \\
N \stackrel{2,056}{=}\end{array}$ & $\begin{array}{c}0.024 \\
(2.1) \\
N=558 \\
0.031 \\
(3.0) \\
N=833\end{array}$ \\
\hline
\end{tabular}

Note.-Given education of husband, husband's years of experience, and square of husband's years of experience.

- See table I for description.

the basic equation was estimated for four 10-year length-of-marriage intervals (table 3 ).

In both estimates ${ }^{13}$ of $\beta_{2}$ the differential increases after the first decade of marriage and declines again during the latter years. The full benefits from association within the household are, therefore, not observed at the time of marriage. These results are consistent with the hypothesis that the rate of postschool capital accumulation within the family during the first years of marriage is a positive function of the wife's education and that the incentives to maintain investment within the family diminish as the working life shortens. ${ }^{14}$

\section{Selective-mating Hypothesis}

Perhaps the principal alternative argument to the family-firm hypothesis for the observed relationship between husband's earnings and wife's education is the hypothesis of selective mating, which in this context asserts that, in an education cohort of males, the more productive males marry more highly educated females. Unfortunately, devising a test which provides clear evidence concerning the relative importance of selective mating versus household-capital formation does not appear straightforward. One difficulty is that, while the household hypothesis has some

13 Only the SEO and U.S. Census data contain information on length of marriage.

14 Since cross-sectional data are used here, there are several problems associated with inferences drawn about life-cycle behavior. The prior lifetime circumstances of younger and older adults were in many ways very different. The younger persons with 12 years of schooling not only had more days in school per year but presumably had better-quality instruction than the older persons. Other characteristics also differed over the age groups, including the proportion who came from agricultural backgrounds and the size of city of residence. It is noteworthy, however, that the pattern was generally the same in 1959 as in 1967. For both dates, husband's earnings as a function of wife's education were higher for the second than for the first decade of marriage, and they declined between the third and fourth decades. This is not consistent with a pure cohort effect. I appreciate the assistance of T. W. Schultz on this point. 
relatively unambiguous implications concerning earnings patterns, almost any result is consistent with some variant of the selective-mating hypothesis. The problems here are similar to those faced in the human capital literature with regard to alternative explanations for the positive correlation between schooling and earnings. Schooling could be either serving as a screening device or augmenting human capital. Our understanding of this latter issue has been due primarily to the accumulation of evidence on the consistency of earnings patterns with implications of the theory of human capital rather than to tests which clearly distinguish between the two hypotheses. Similarly, no clear tests of the household-capital versus the selective-mating hypothesis are examined here, but some evidence can be brought to bear on this issue.

If the selective-mating hypothesis is refined to mean that, within a given education cohort of males, the more productive males marry females who are more highly educated at the time of marriage, it implies that a husband's earnings should be much more strongly associated with his wife's premarriage education than with her postmarriage education, ceteris paribus. The educational attainment of the wife at the time of marriage is not indicated in any of the data samples used, but the wife's age at the time of marriage is included in the U.S. Census and SEO data, and from this two indirect tests can be made. First, an examination is made of the relationship between the wife's age at marriage and her husband's earnings. The argument is that, for any given level of a wife's schooling, the younger she is at the time of marriage the less likely she is to have completed her education, and hence, according to the variant of the selective-mating hypothesis proposed above, the less likely she is to marry a highly productive male. This hypothesis is not supported by table 4, which shows the partial relationship between wife's age at marriage and husband's earnings to be consistently negative. ${ }^{15}$

An alternative way of examining this same question is to estimate the years of education completed by the wife at the time of marriage and to examine the husband's earnings differentials associated with his wife's pre- and postmarriage education. The estimates in table 5 suggest that the relationships between wife's pre- and postmarriage education and husband's earnings 'are very similar, ${ }^{16}$ that women's postmarriage

${ }^{13}$ Several alternative forms of the variable "age of wife at marriage" were considered. These included dummy variables for each marriage age (18-25) and combinations of continuous and dummy variables. For those women marrying either at a relatively young age ( 18 or under) or at a relatively late age ( 25 and over), husband's earnings were generally lower than for women married between ages 18 and 25 . For the intervening years, the association between wife's age at marriage and husband's earnings was either negative or essentially zero. An alternative hypothesis consistent with results in table $\mathbf{4}$ is that wife's age at marriage is serving as a proxy for husband's work experience.

${ }^{16}$ These estimates should be viewed somewhat cautious!y, since a purely random division of education would push the pre- and postmarriage coefficients toward equality. 


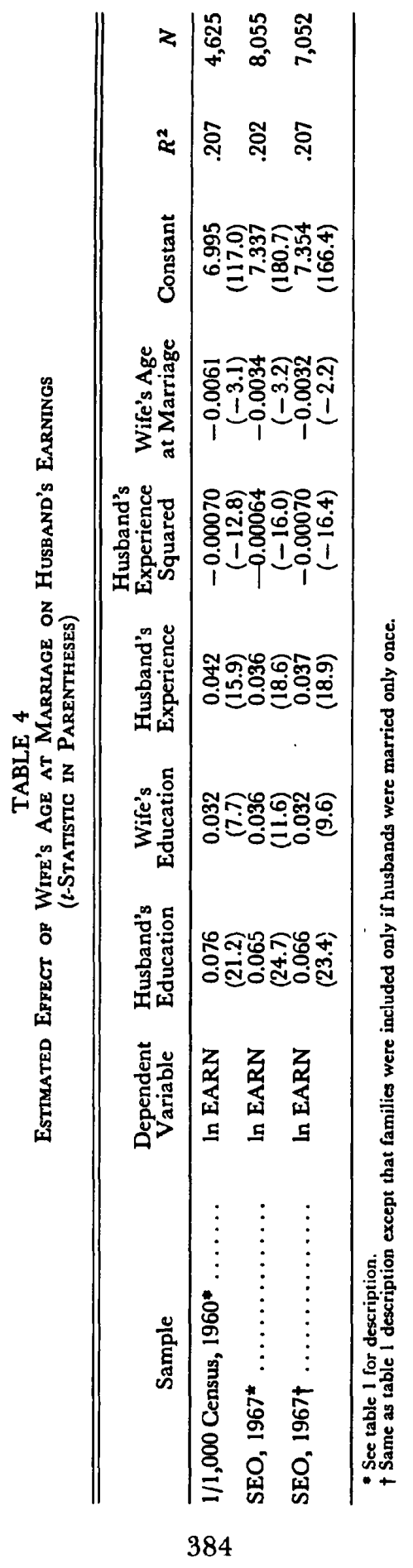




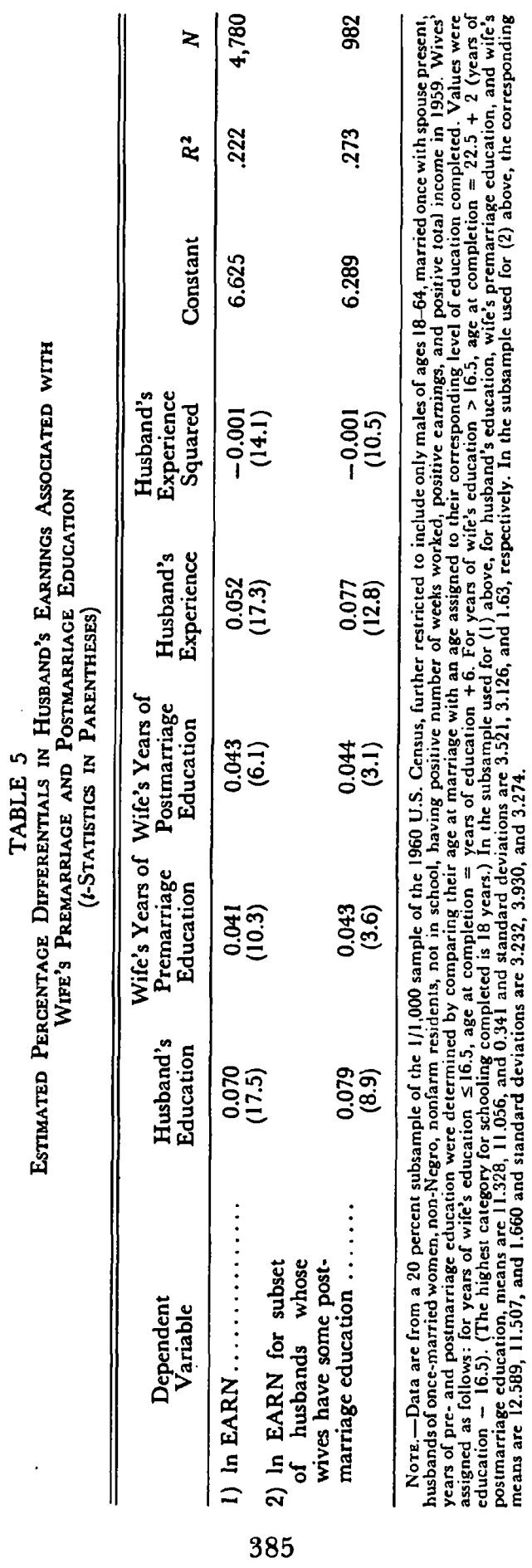


education is at least as strongly associated with husbands' earnings as is their premarriage education. ${ }^{17}$

Another variant of the selective-mating hypothesis states that a wife's education is only a proxy for other background characteristics of both spouses, such as intelligence and social class. Should these latter variables be associated both with husband's earnings and with wife's own educational attainment, then the association noted between the wife's education and the husband's earnings may be spurious. This argument has its counterpart in the recurring question of the extent to which an individual's education itself results in higher earnings versus the extent to which education is merely a proxy for intelligence, social background, and so forth.

Data on background variables were not available in the samples used for tables 1-5. However, this issue has been examined in another context by Duncan, Featherman, and Duncan $(1972$, p. 178) in a study of the relationship between the occupational status of husbands and the background characteristics (including education) of both spouses. ${ }^{18} \mathrm{~A}$ multiple regression was computed of husband's occupational status in 1956 on his background characteristics, including his education, his occupational status at marriage and his father's occupational status, and his wife's background characteristics, including her education, her father's occupational status, her intelligence, and a psychological index of her drive to get ahead. All the coefficients for wife's characteristics except education were less than two times their standard error. This is consistent with the hypothesis that the wife's education has a significant independent effect on the husband's career development.

These results, however, are not directly comparable to those presented in tables 1-5, since occupational status rather than earnings is the dependent variable. By using another data set developed by Blau and Duncan (1967), it is possible to obtain more directly comparable results by estimating the relationship between husband's income in 1961 and both spouses' education, given several of the husband's background

17 An alternative explanation concerning the strong relationship between wife's postmarriage education and husband's earnings is that husbands with higher earnings purchase more postmarriage education for their wives. To examine this question, a sample was drawn of husbands of ages 20-30 having 12 or more years of school who were employed full time during the week of the 1960 U.S. Census survey. For this group, median income was calculated for husbands whose wives were in school and for those whose wives were not in school. Only 2.4 percent of the men in this sample had a wife in school, so results should be viewed with appropriate caution; but in all men's education categories except 12 years, the median income was lower for those men with wives in school.

${ }_{18}$ The data used for these estimates were for couples who had recently had a second child at the time of the survey in 1957 (see Duncan et al. [1972, p. 34] for a more complete description). 
characteristics, including occupational status of his first job and his father's occupation and education. ${ }^{19}$

The following three specifications were used to estimate the impact of including husband's background characteristics using these data:

$$
\begin{aligned}
\mathrm{INCOME}= & \alpha_{1}+\beta_{1} \mathrm{EDH}+\beta_{2} \mathrm{EDW}+\mu, \\
\mathrm{INCOME}= & \alpha_{1}+\beta_{1} \mathrm{EDH}+\beta_{2} \mathrm{EDW} \\
& +\beta_{3} \mathrm{EDHF}+\beta_{4} \mathrm{OCHF}+\mu, \text { and } \\
\mathrm{INCOME}= & \alpha_{1}+\beta_{1} \mathrm{EDH}+\beta_{2} \mathrm{EDW} \\
& +\beta_{3} \mathrm{EDHF}+\beta_{4} \mathrm{OCHF}+\beta_{5} \mathrm{OCHJ}+\mu,
\end{aligned}
$$

where INCOME = husband's income in 1961, EDH = husband's education, $E D W=$ wife's education, $E D H F=$ husband's father's education, $\mathrm{OCHF}=$ husband's father's occupation, and $\mathrm{OCHJ}=$ husband's occupational status on his first job. Due to the nature of the available data, ${ }^{20}$ these specifications differ from the earlier ones in this paper in that income rather than ln earnings is the dependent variable and husband's work experience is not included. ${ }^{21}$ Nevertheless, they provide qualitative estimates of the relative importance of husband's background characteristics.

Table 6 shows the relative impact of wife's education as compared with husband's education on husband's income $\left(\beta_{2} / \beta_{1}\right)$ by age of wife. These estimates are consistent with those presented earlier. There is a substantial relationship between wife's education and husband's income in most years. For wives of ages 22-26, husband's income increases 37 percent as much with an increase in wife's education as with a similar increase in husband's own education. This ratio increases to 80 percent for wives ages 32-36 and then declines at older ages, a pattern similar to that shown in table 3 .

When husband's father's occupation and education are included, the pattern is very similar. ${ }^{22}$ Except for the oldest group, these results are not consistent with the hypothesis that the association between wife's education

19 Data were collected from 20,700 respondents representing men in the U.S. civilian noninstitutional population between the ages of 20 and 64 in March 1962 (see Duncan et al. 1972, p. 32).

20 Professor Otis Dudley Duncan generously provided the correlation matrices which he had developed for table 8.16 in.Duncan et al. $(1972$, p. 240). The estimates shown here were calculated from those matrices.

${ }^{21}$ The consequences of excluding the husband's work-experience variables are less severe here since separate estimates are made for each of eight age-of-wife categories.

22 Inclusion of father's education and occupation reduces the education coefficient for both spouses. The ratio of the husband's education coefficient when his father's education and occupation are included to the husband's education coefficient when they are excluded, by wife's.age, is as follows: wife's age 22-26 (.91), 27-31 (.81), 32-36 (.80), 37-41 (.82), 42-46 (.87), 47-51 (.85), 52-56 (.85), and 57-61 (.80). 
TABLE 6

Ratto of Increase in Husband's Income as a Function of Wife's Education to InCREAse in Husband's Income as a Function of Husband's Education, for Intact White Couples, by Age of Wipe in 1962

\begin{tabular}{|c|c|c|c|c|c|c|c|c|}
\hline \multirow{2}{*}{$\begin{array}{l}\text { INDEPENDENT } \\
\text { VARIABLES } \\
\text { INCLUDED }\end{array}$} & \multicolumn{8}{|c|}{ AgE of WIFE } \\
\hline & $22-26$ & $27-31$ & $32-36$ & $37-41$ & $42-46$ & $47-51$ & $52-56$ & $\overline{57-61}$ \\
\hline $\begin{array}{l}\text { Husband's and wife's } \\
\text { education } \ldots \ldots \ldots \ldots\end{array}$ & $.37^{*}$ & $.51 \dagger$ & $.80 \dagger$ & $.46 \dagger$ & $.25 \dagger$ & $.35 \dagger$ & $.16 \dagger$ & $.14 *$ \\
\hline $\begin{array}{l}\text { Husband's and wife's } \\
\text { education, husband's } \\
\text { father's education } \\
\text { and occupation .... }\end{array}$ & $.36^{*}$ & $.57 \dagger$ & $.93 t$ & $.49 \dagger$ & $.24 \dagger$ & $.33 t$ & $.14 *$ & .05 \\
\hline $\begin{array}{l}\text { Husband's and wife's } \\
\text { education, husband's } \\
\text { father's education } \\
\text { and occupation, and } \\
\text { husband's occupa- } \\
\text { tion at first job .... }\end{array}$ & $.41^{*}$ & $.62 \dagger$ & $1.22 \dagger$ & $.52 \dagger$ & $.26 \dagger$ & $.37 \dagger$ & $.18^{*}$ & .04 \\
\hline
\end{tabular}

and husband's income is predominantly due to selective mating based on wife's education and these background characteristics of husband.

When the husband's occupational status on his first job is included, the wife's education remains statistically significant for wives between ages 27 and $51 .{ }^{23}$ Selective mating based on the husband's occupational status on his first job does not explain the association between his income and his wife's education.

Obviously, other evidence will be required before the relative importance within the family of selective mating versus benefits of wife's education can be determined. However, a significant positive relationship between husband's earnings and wife's education, given the husband's own education and job experience, has been found, and further evidence has been examined which might have contradicted the household hypothesis but which instead was found to be consistent with it.

\section{Conclusions}

Several tentative conclusions may be drawn from the results above:

1. A shift in emphasis from the individual to the family unit may not only facilitate understanding of productivity and efficiency within the

23 Not surprisingly, when husband's occupational status on his first job is entered, the coefficient of husband's education is reduced. The ratio of husband's education coefficient when father's background characteristics and husband's occupational status on first job are included to husband's education coefficient when only the spouses' own educations are included, by age of wife, is as follows: wife's age 22-26 (.67), 27-31 (.70), 32-36 (.57), $37-41(.69), 42-46(.72), 47-51(.66), 52-56(.67)$, and 57-61 (.57). 
home but also usefully extend our understanding of the effects of education on labor-market productivity.

2. The traditional human capital literature has emphasized formal schooling and on-the-job training as the locations where individuals accumulate their human capital. The results in this paper are consistent with the view that there is substantial capital accumulation within the household.

3. Labor-market benefits to men appear to be associated with their marrying well-educated women. These benefits have implications not only for earnings but also for the characteristics of marriage partners selected and the stability of marriages.

4. The wife's education provides substantial labor-market benefits to the family beyond increments to her own earnings. Both the private and social market returns to women's education may be higher than has been generally believed. The flavor of some past discussions of women's education has suggested that it is an indulgence of an affluent society. Perhaps the affluence has been more a function of women's education than has been heretofore realized. 


\section{Comment}

\section{Finis Welch}

City University of New York and National Bureau of Economic Research

I have been tempted to write a note on the social cost of the "marriagego-round." In a nutshell, the idea is that more productive marriage partners are preferred and that, on balance, net productivity in marriage is positively related to education. Increased education serves to increase an individual's chance of a good marriage, of marriage to a "more" educated spouse. If an individual's social product is independent of his spouse's education, then the marriage-go-round results in overinvestment in education. Benham's view that a person's own productivity depends on attributes of the spouse is a clear alternative.

My skepticism concerning Benham's hypothesis that a husband's earning capacity is positively related to his wife's schooling is not qualitative but quantitative. How important are these (very likely positive) cross-productivity effects? I was not surprised to hear of the positive association between wife's schooling and husband's earnings. I was surprised that most emphasis is on productivity instead of selective mating.

Benham points out that, since his measures are of annual earnings, there may be labor-supply effects submerged in the estimated relationship between husband's earnings and wife's schooling. He notes (correctly) that the direction of this effect is unclear on a priori grounds, but finds empirically that an extra year of wife's schooling has only a slightly smaller percentage effect on husband's weekly wage than on annual earnings. In tabulations using a different body of data, I have verified this result. I will briefly describe these computations.

I used the NBER-Thorndike sample of 4,519 white married males (wife present) who entered the U.S. Air Force in 1943 and who were examined as navigators and pilots at that time. Earnings are for 1969. Experience is the number of years since the individual was last in school. The geometric mean of earnings is over $\$ 13,000,{ }^{1}$ and logarithmic variance is 0.24 .

${ }^{1}$ Earnings for 1969 are deflated to the 1958 value so as to allow life-cycle comparisons. In the regressions below, I did not rescale this variable. 
The advantage of this sample is that data are available to permit explicit consideration of the possible effects of selective mating. For example, information on husbands includes: (1) schooling, (2) a measure of IQ, (3) father's schooling and occupation, and (4) religion. It is clear that the sample is rarefied, and it is consequently hard to judge how much confidence should be placed in results contained within: For example, essentially all respondents are white, completed high school, and on armed forces intelligence tests scored in the upper one-half of the distribution. On the other hand, in one important dimension, this sample is superior to the national probability samples for isolating "pure" productivity effects of wife's schooling. It is likely that the World War II marriage market functioned somewhat differently from that in normal timespossibly a careful matching of family background was less important during the war. If so, then in this sample, containing a disproportionately large number of men who were married during the war, there should be less "pollution" with covariance between wife's schooling and husband's family background. ${ }^{2}$ For example, Benham, in an unpublished table, shows that, in the U.S. Census sample, the zero-order correlation between husband's and wife's schooling is 0.65 . In the NBER-Thorndike sample the correlation is 0.38 .

It is true that this lower correlation in the NBER-Thorndike sample could be the result of truncation in the husband's schooling variable, but it is important that if truncation reduces correlations it does not change biases due to omitted variables. Yet, if the reduced correlation follows from reduced covariance between wife's schooling and omitted variables such as husband's IQ or family background, which may themselves affect earnings, then the reduced correlation reduces coefficient bias. Table 1 reports regression results for this sample.

Regression 1 is equivalent to regressions Benham presents in table $1 \mathrm{~A}$, and the results agree that there is a "significant" association between wife's schooling and husband's earnings. There is a quantitative difference, however; while a year of schooling for the husband has the same estimated effect (6-7 percent) on earnings, the coefficient for wife's schooling is less than one-half as high in the NBER-Thorndike sample as in the samples used by Benham. Regression 2 includes the length-of-marriage variables à la Benham's table 3. Here no evidence of a statistically significant relationship exists. The computed $F$-statistic $(2 ; 4,512$ degrees of freedom) is only 1.16. In any case, it is hard to interpret Benham's results vis-à-vis length of marriage, for the marriage can itself be considered as a short "period of investment."

Regression 3 introduces a decomposition of the wife's schooling variable into two parts. The first part includes those components of a wife's

2 Roughly 17.5 percent of the NBER-Thorndike sample of men who had wives in 1969 had married those particular spouses between 1941 and 1944. Of this group of men, 8 percent were married in 1944. 


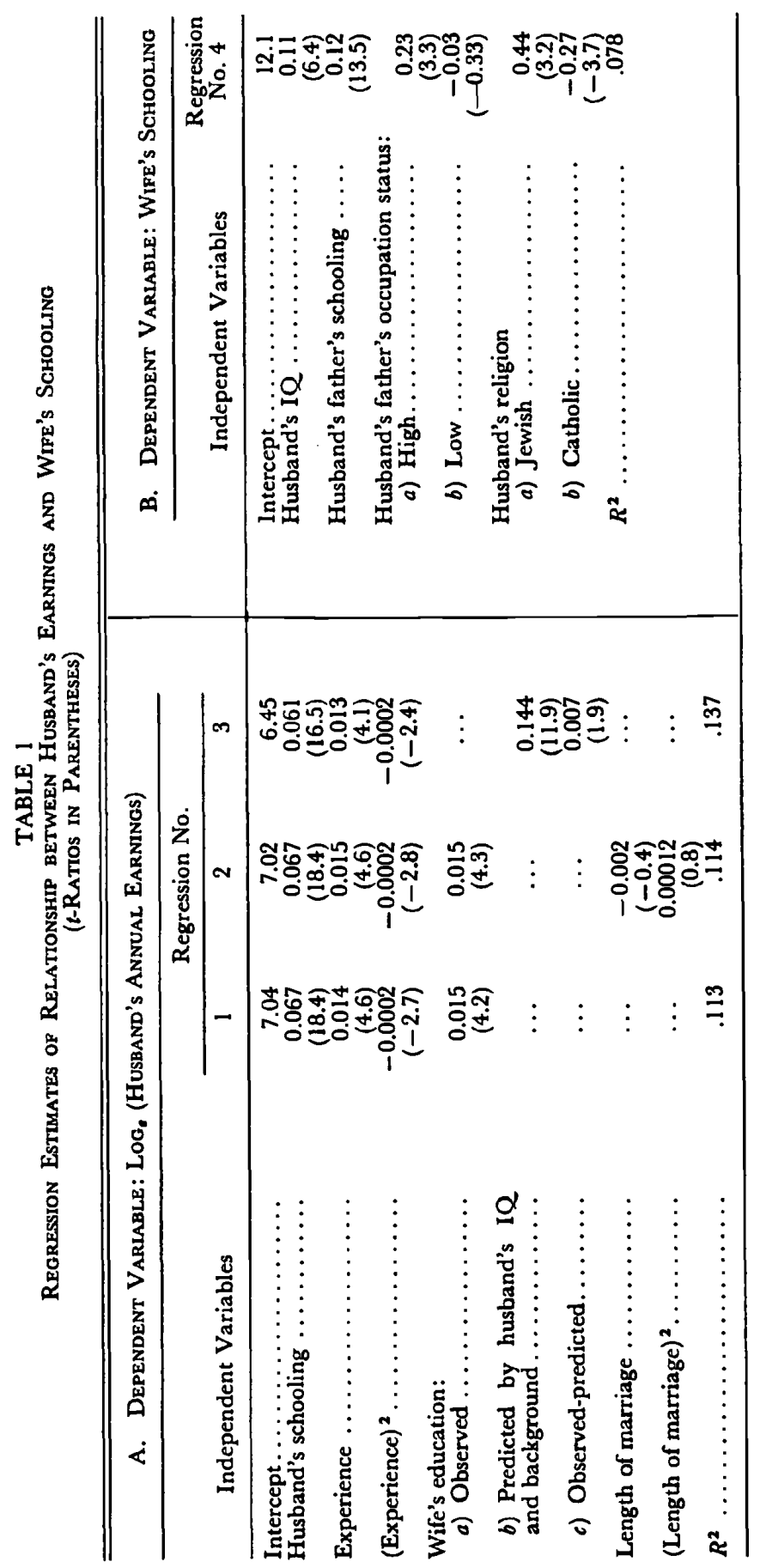


schooling that are correlated with (and presumably would be predicted by) her husband's IQ, religion, and his father's schooling and occupation. The intention is simply that these variables would be among the most obvious predictors of wife's schooling, based on a sociological "network" or an assortive-mating frame of reference. The second part of the wife's education is that which. is orthogonal to the above list and is simply the residuals between observed schooling and schooling predicted by regression 4. It is this part of a wife's schooling that is independent of her husband's background, religion, and measured IQ which is the obvious candidate for the "pure" productivity effect posited by Benham. But in these data there is little independent role for wife's education. Most of the effect is channeled through the independent variables of regression 4.

To summarize these results, note first that the effect of a year of a wife's schooling is 22 percent of the estimated effect of her husband's schooling. Further, after "partialing out" effects of a husband's IQ and background on his wife's schooling, the net effect of the wife's schooling is reduced to slightly less than half its original level and the coefficient estimate is of marginal statistical significance. The estimated net effect of a wife's schooling is roughly one-tenth of the estimated effect of her husband's schooling and is only one-fifth of Benham's estimate.

Does this then prove that the pure productivity effect is unimportant? Clearly not. Aside from the peculiarities of this particular set of data, the identification problems surrounding the Benham hypothesis are probably insurmountable. For example, consider models of selective mating. If forces for selectivity exist in the absence of this cross-productivity (crossfertilization?) effect, they are clearly magnified by its existence. 
